\title{
MAX Gene
}

National Cancer Institute

\section{Source}

National Cancer Institute. MAX Gene. NCI Thesaurus. Code C18576.

This gene is involved in transcriptional regulation and plays a role in the mediation of

DNA-protein interactions. 